\title{
Working-class conservative voters in 2019: voices from a valley in northern England
}

\author{
Gavin Hart ${ }^{1,2}$
}

Accepted: 5 May 2021 / Published online: 20 May 2021

(c) The Author(s), under exclusive licence to Springer Nature Limited 2021

\begin{abstract}
This paper highlights the findings from qualitative research into the electoral decision-making processes of working-class Conservative voters from a constituency in northern England. Through focussing specifically upon their primary concerns during the 2019 election, the piece expands upon existing quantitative research. Survey studies have highlighted leadership concerns and Brexit as the primary factors that have driven voters away from Labour and towards the Conservative Party. It is argued here that leadership, Brexit, and economic management were closely intertwined, with party leaders at the centre of broader thinking for these participants. Perceptions of the party leaders were foremost in these deliberations and this has clearly impacted upon the interviewees' thinking on a range of political matters. Additionally, the interviews asked what might influence the participants' future electoral choices. Here, the data suggest a sense of limited, qualified attachment to the Conservative Party and a desire to see the Labour Party move towards what the respondents perceive as a centrist ideological position. The final section considers what these findings may mean for the major parties in future electoral contests. It is suggested that the presidential focus has worked for Johnson so far due to his abilities as a communicator, but the government will have a difficult hill to climb in this parliament if they are to retain the loyalty of these voters in future.
\end{abstract}

Keywords Jeremy Corbyn · Boris Johnson · Elections $\cdot$ Leadership · Social class

Gavin Hart

g.hart@hud.ac.uk

1 Centre for Citizenship, Conflict, Identity and Diversity, University of Huddersfield, Huddersfield, UK

2 Division of Criminology, Politics and Sociology, University of Huddersfield, Ramsden Building, Queensgate, Huddersfield HD1 3DH, UK 


\section{Introduction}

The 2019 election saw important shifts in electoral support across geographic and socio-economic fault-lines. The Conservative Party achieved a decisive victory, and the Labour Party suffered notable defeats in constituencies that had traditionally formed the party's northern, working-class stronghold (Curtice 2020). The Conservatives successfully courted these voters through explicit appeals to pro-Brexit sentiment and conservative social values (Cutts et al. 2020). There are both long-and short-term factors that explain the extent of Labour's defeat in this election. It is correct to state that the party has suffered a long-term decline in Scotland and weakening support in its heartland constituencies (Carreras et al. 2019). There were also some highly influential short-term factors on the table that should be given due consideration. As the Labour Party has sought to make sense of this defeat, two competing narratives have emerged from the internal debate: Corbyn loyalists have argued that the outcome was the product of a Brexit election in which Labour was 'caught in a vice' despite the broader popularity of their economic offering (Elliot et al. 2020). However, many of the former Labour MPs who lost their seats at this election blamed the reluctance of voters to back Jeremy Corbyn for the role of Prime Minister (Morris 2019). This raises questions as to which of these factors was most prevalent, and how these issues were incorporated into the thinking of the northern, working-class voters that were so important in shaping the result of this election.

Polling research carried out in the aftermath of the election confirmed that leadership was most commonly cited as the reason that former Labour voters switched to the Conservative Party; Brexit was a close second; and economic management issues were third (YouGov 2019a). This study delves into the views of these voters as they took shape in 2019. It will be argued here that for the northern, working-class Conservative voters who contributed to this study, that these issues were closely interwoven. Questions about leadership acted as a lynchpin that held other factors together. Perceptions of the Labour leadership, particularly Corbyn, were at the centre of broader thinking across a range of policy issues.

This article outlines the key findings from qualitative research carried out with self-identified, working-class Conservatives voters, from a constituency in northern England that swung from Labour to Conservative during the 2019 election. The participants were asked open questions about what was most important to them when deciding which party to vote for. Additionally, respondents were asked to discuss how attached they were to the Conservative Party, and what factors they thought would be likely to shape their voting preferences in future. The most common responses revolved around the party leaders.

Interviewees provided a negative appraisal of Jeremy Corbyn contrasted with a broadly favourable perception of both Boris Johnson and Tony Blair. Beyond this focus on leadership, the participants brought up Brexit and economic management as the most important issues that had impacted upon their choice of vote. However, when these policy areas were discussed, the respondents intertwined 
their narratives on these issues with their negative views on Corbyn and positive assessments of Boris Johnson as potential Prime Ministers. Studying these narratives highlights the extent to which a presidential lens gave focus to the political thinking of this group: leaders were central to all aspects of the wider decisionmaking process.

Furthermore, the participants generally spoke of a relatively limited attachment to the Conservative Party. Respondents commonly expressed a preference for voting for Labour if the party changed leader and moved towards what they perceived as the centre-ground. Collectively, this evidence seems to suggest that Labour may be able to win back some of these voters under Starmer's leadership, if the party can project a more moderate image in future. Particularly, these voters wish to see the Labour Party move to a more frugal position on public spending. This argument will unfold as we progress through the article, but in the first instance, it is useful for us to provide an overview of the 2019 election results. The purpose of this will be to build foundations that highlight the importance of studying northern, working-class Conservative voters to further our understanding of the shifting fault-lines in British electoral politics.

\section{The 2019 election}

In order to underpin this research into northern, working-class Conservative voters, it is necessary to consider the electoral patterns that emerged in the 2019 election. Whichever way you look at this contest it is hard to say that it was not disastrous for Labour. Losing 59 seats is not a good outcome for a party that has sat on the opposition benches for nearly a decade (Hughes 2019, para 2). Conventional wisdom and academic research agree that long-standing governments will tend to decay in office and that the opposition will gradually gain electoral leverage as a consequence (Heppell 2008). In this instance, that trend has been bucked with Boris Johnson's reinvigorated Conservative Party gaining 47 seats in 2019 (Heffer 2019, para 4). This in itself is a striking turnaround that pushes against the grain of what we would normally expect from a party that has spent so long in government. Of further concern to the Labour Party are the particular constituencies that have swung from red to blue in this election.

Labour's high-profile losses and the impressive Conservative gains are well documented, but it is useful to provide a brief overview of some of the particularly hardhitting features of this changeover. The Conservatives captured constituencies all across the so-called 'red-wall' of Labour's former working-class strongholds in the midlands and northern England. Seats such as Blythe-Valley and Bolsover-constituencies that have been held by the Labour Party since their creation-fell under Conservative control for the first time (Halliday 2019). Polling data highlighted the fact that the Conservative Party had captured $48 \%$ of votes cast by those in the CD2E socio-economic category compared with 33\% that voted for Labour (YouGov 2019b). This represents quite a blow for a party that was specifically formed to represent the political interests of the working class. The party has traditionally depended upon the loyalty of northern England to maintain its electoral relevance. 
However, the 2019 election was not a sharp turn in the road. Rather, it was a significant marker on a path that has seen Labour gradually losing its connection with voters in Northern England since the late 1990s (Labour for the North 2020). This general trend has been reflected by shifts in the focus of academic debate on British politics in recent decades. This is evident when we survey some of the important scholarship that has engaged with class politics in the UK.

\section{Social class and partisan alignment}

Social class held a dominant position in the study of electoral politics in advanced liberal democracies during the early part of the twentieth century (Clarke and Lipset 1991). Observations made by political scientists writing in the 1960s suggested that class was the key determinant of voting behaviour in the UK. Writing about developments in British politics in the late 1960s, Peter Pulzer observed that "Class is the basis of British party politics; all else is embellishment and detail" (Pulzer 1967, p. 98). However, as the latter part of the twentieth century progressed, the connection between socio-economic class and voting behaviour became less pronounced.

It is fair to say that while social class has been a key feature in scholarly texts on British politics, it has waned as an explanatory concept since the 1980s (Lilleker 2002). A significant body of literature has been devoted to debates over class dealignment (Crewe 1986; Heath et al. 1987; Dunleavy 1987). Such scholars have tended to focus their attention on the extent to which it is appropriate to characterise voting behaviour in class terms; how closely class has been related to party choice; and whether the relationship between class and parties has modified over time. Despite wide ranging debate in this area it is largely accepted that class voting has declined in significance since the late twentieth century, even though it still holds some explanatory power (Evans and Tilley 2012). It is certainly the case that longterm shifts in the British economy have undermined any sense of partial homogeneity across the working-class that might have existed in the early part of the twentieth century (Savage et al. 2013). Furthermore, social identification has diversified due to a range of factors that can be broadly understood as part of a non-material turn in contemporary politics (Inglehart 1977; Hall and Jacques 1989). These wider structural shifts have been accompanied, and augmented, by related developments in British party politics.

In the UK, as it became apparent that the Labour Party could not expect to govern through making purely sectional appeals to working-class voters, both of the governing parties have sought to frame society in post-class terminology. For Thatcher, this meant referring to society in terms of a small underclass, a slim social elite, and the vast majority of 'ordinary working people'. For Major, this sentiment was captured in the phrase 'classless society'. Blair deliberately refrained from making explicit class-based appeals: speaking in terms of a merging of the working and middle classes (Sutcliffe-Braithwaite 2017). Under Blair, New Labour managed to successfully build a coalition of middle-class Labour voters and traditional working-class partisans that enabled the party to govern. However, many voters in the 
so-called 'red wall' increasingly tended to abstain from voting or to support nativist parties such as the BNP or UKIP during this period (Ford and Goodwin 2010).

Labour's connection to its 'heartland' vote has waned over a long period of time (Evans and Mellon 2020; Labour for the North 2020). With this connection withering, a class-based analysis of voting behaviour has seemed less central to the study of British politics. The 2019 election proved to be a turning point as voters in these areas came out in such significant numbers to support the Conservative Party. This shift in the electoral landscape has been described as period of 'class realignment' as scholars have noted a tendency for working-class voters to support the Conservative Party, and the majority of support for the Labour Party to come from sections of the middle class (Cutts et al. 2020; Evans and Mellon 2020).

This development has put social class firmly back under the microscope amongst scholars devoted to the study of electoral politics in the UK. It remains to be seen whether this realignment is likely to hold in the future, or whether it is a product of the specific circumstances of this election. Only future elections will tell us how permanent this realignment will be. However, we can start to investigate how strongly northern working-class Conservative voters identify with their party of choice to provide an indication of the depth of this electoral shift. This case-study contributes to this body of research by providing an in-depth analysis of working-class Conservative voters in a seat that recently moved from Labour to Conservative. The research offers insight into their specific thoughts on political matters and their electoral decision-making processes. Before we proceed to outline the findings of the investigation, it is appropriate to devote some brief consideration to how the study was carried out, and the methodological choices that have been made in order to capture these views.

\section{The case-study}

Firstly, it must be made clear that Colne Valley constituency is not considered to be a part of Labour's so-called 'red wall'. The seat has been a marginal constituency that has been held by either Labour or the Conservative Party since 1987 (Parliament Online 2020). During this period, the electoral outcome in the Colne Valley has usually followed national trends, with the winner of the seat being a representative of the victorious party. The exception to this was in 2017, when Labour took the Colne Valley but the Conservatives won the election (General Elections Online 2020).

The wider borough of Kirklees in which the Colne Valley is situated voted to leave during the 2016 referendum on EU membership, though further analysis has suggested there may have been a marginal remain majority within the constituency itself (Lavigueur 2017). For these reasons, this makes for a slightly unusual case-study for investigating the northern, working-class voters that influenced the outcome of the 2019 election. However, the seat is one that Labour would need to regain were the party to hope to govern again. Furthermore, this will be the type of constituency that the Conservatives would hope to consolidate and build upon in future elections. The strategic importance of the seat was illustrated by the presence 
of high-profile figures from both parties on the campaign trail in 2019. The Labour campaign saw frontbench figures such as John McDonell, Angela Rayner and Richard Burgon come to support the local candidate; and the Conservatives were supported by appearances from Matt Hancock and Gavin Williamson (Lavigueur 2019). As a swing seat in northern England, the Colne Valley can deliver important tranches of data that are indicative of wider trends. Through carrying out a case-study of this type we can add nuanced detail to existing survey data that have focussed upon these electoral trends.

Participants in the study were recruited by a campaign on the Facebook platform in the immediate aftermath of the 2019 election. A digital flyer was placed upon a small selection of Facebook pages that acted as social media community hubs for each of the villages that collectively comprise the Colne Valley. The request asked for participants who identified as working class, and voted Conservative in 2019 in the Colne Valley constituency. No further criteria were set in the recruitment process. It must be recognised of course that there are various measures of social class ranging from an occupationally focussed structure such as the Goldthorpe et al. model (1982), through to more culturally based approaches such as that put forward by Savage et al. (2013). For the purpose of this study it was decided to draw upon an identity focussed framework based broadly on Eidlin's (2014) model. This is to say that rather than pigeon-holing participants based upon arbitrary measures of wealth, or cultural capital, they were asked to self-select on the basis of their own sense of social class. Participants were asked as part of the interview to define what class meant to them, this produced interesting results that will be explored further in forthcoming publications.

Adopting this flexible approach yielded 14 participants in the weeks immediately following the 2019 election, and a further seven participants were recruited on a word-of-mouth basis later in the research process. This created a total pool of 21 interviews all of which were used to support the investigation. It must be stated that 21 interviews represent a very small sample of the electorate, and the data should be treated with caution when attempting to make broad generalisations. However, given that there are a range of large-scale survey studies that have been carried out in this area (see YouGov 2019a, b for example) the importance of this work is to capture elements of the nuanced thinking of the respondents, so that we might develop a deeper understanding of their specific thought processes (Hollway and Jefferson 1997). The interviews were carried out until well after saturation point was reached and respondents were replicating similar narratives throughout their discussions (Dworkin 2012).

The respondents that came forward were exclusively white men, mostly working in blue-collar occupations, with an age range between 32 and 68. This particular demographic was not actively sought out in the advertisement for participants. All except one of the participants had previously voted for the Labour Party, though their point of transition to the Conservatives varied across a range of elections since 2005. Only one of the participants had voted Conservative for the first time in 2019. The only criteria that was set for interviewees was that they must live and vote in the Colne Valley constituency, consider themselves to be working class, and to have voted for the Conservative Party in the 2019 general election. Interviewees in this 
study will be quoted by the use of pseudonym with references to their general area of occupation in order to ensure their anonymity.

The interviews were conducted on a one-to-one basis either in person, or by telephone. The respondents were asked to explain what factors had been most influential in shaping their vote choice. This allowed interviewees the flexibility to discuss their own priorities and to raise the issues that they deemed to be the most pertinent to their deliberative processes. Participants were prompted to develop their arguments by questions about how they had arrived at their decisions and where their political information came from, but specific political issues were not raised by the interviewer in order to ensure that the participants were leading the conversation. Additionally, respondents were asked to consider how they might vote in future elections in order to assess how firmly they identified with the Conservative Party.

The data captured from these interviews provide a unique insight into how a particular section of the electorate in a marginal seat arrived at their voting conclusions. The research illustrates the particular discursive formations that this group utilises in order to construct their distinctive vision of the political sphere. The findings are valuable to both the Labour Party as it seeks to recapture a key section of the electorate, and the Conservative Party, as it looks to develop a firm hold on recent electoral gains. Let us now turn to examine a selection of the most important data that has arisen during this research process. What follows is not an exhaustive account of every aspect of the interviews, but it does provide a solid indication of the main factors that were discussed by the participants. The first area that we will review pertains to matters related to leadership and the party leaders.

\section{Results 1: leaders and leadership}

When participants were asked what had driven their electoral choices, the most common response was to discuss the party leaders. This included perceptions of their leadership qualities and their likeability. In these discussions, Jeremy Corbyn was generally the subject of deeply negative characterisations, whereas Boris Johnson was perceived more favourably, often as relatable and amiable. There were exceptions to these general trends though these were infrequent. Throughout the research process it became clear that to a large extent, the participants viewed the election in presidential terms, with leaders seen as the embodiment of their parties and as the central players in the electoral landscape.

The importance of party leaders for influencing the voting decisions of the electorate has been the subject of a significant scholarly debate on British politics (King 2002; Mughan 2009). This is tied into broader questions about the nature of Prime Ministerial power and charges of increasing presidentialism (see Dowding 2013; Webb and Poguntke 2013). Broadly speaking, the debate is divided between those who see party leaders as influential in shaping the opinions of voters independently of their wider party, and those who argue that parties are the key in driving voter preference with leaders playing a bit-part role in this process (Mughan 2015). The data explored here do not enable us to rule definitively on how influential leaders are in comparison with broader issues of partisan 
identification. However, the data indicate that for the Northern, working-class, Conservative voters who participated in this study, that assessments of the party leaders played a crucial role in their decision-making process. This becomes evident when we move to examine a selection of quotations that pertained to Corbyn as a potential Prime Minister:

I couldn't vote for Corbyn. I didn't want him to lead my country. I just don't think that he is a strong enough leader. I didn't like how he talked, I didn't like how he came across on the leader's debate or whenever I saw him on telly. He seemed bitter to me (Dave, retail worker 2020, personal communication, 15th February).

The quotation above discusses a perception of weak leadership on Corbyn's part, but also makes observations about his general lack of appeal to this participant. Similar remarks were made throughout the data. The quotation below makes a similar point about a judgement of weakness in relation to matters of national security. This is combined with a negative appraisal of Corbyn lacking consistency due to perceived differential standards for his personal security and that of the United Kingdom:

Corbyn just isn't a leader. He wants to get rid of the country's security and armed forces, but he walks around with six security guards. So straight away that tells me that he is all for himself. It's like he's out to create bother. He's a hypocrite, isn't he? (Richard, plasterer 2019, personal communication,14th December).

If Corbyn was perceived mostly negatively-in terms of his personal characteristics and leadership qualities - the obvious next question is to consider how interviewees responded to Boris Johnson. In contrast, Johnson was mostly discussed in positive terms during these interviews. In the first instance, many participants spoke of Boris Johnson in terms of a relatable and likeable character. This is captured in the quotation below, in which the participant views Johnson favourably due to a sense of him being a humorous personality. We also see Johnson referred to in first-name terms which was a common occurrence across these interviews:

I like Boris. I first liked him back in 2012, the Olympics. He won everyone over. I think he was popular in London when he was Mayor. He's fun, he's a laugh. Sometimes you need leaders who are like, not all doom and gloom (John, warehouse operative 2019, personal communication, $21^{\text {st }}$ December).

In the quotation below, we see a similar point raised about a general likeability associated with Boris Johnson and his particular rhetorical style. This was taken from a discussion in which a participant was referring specifically to Johnson's performance during the leadership debates that took place during the election campaign:

I guess Boris was probably taught to speak in a certain way. To bumble a bit and to come across likeable. He's got it down to a fine art. They could've pulled him up, called him a liar, you know? They could have proved he was a liar but he was still likeable (Peter, joiner 2020, personal communication, 8th February). 
A number of participants made specific reference to perceptions of Johnson's social class and elite education. Generally, this was spoken of in positive terms and drew upon deferential assumptions about who was best suited to govern the country:

People say Boris is too posh. It doesn't bother me if he's posh. I would rather our leaders went to the best schools and were the smartest people and make the best decisions. I think we vote for people to make these tough decisions for us. I want them to be far more educated than I am (Steve, engineer 2020, personal communication, 14th March).

Participants would often move seamlessly between speaking in terms of Johnson as an elite figure and their perception of him as a 'regular guy'. This frequently came up in relation to his coverage in the media and in response to allegations of marital infidelity or absentee parenting. This is evident in the fragment below, in which the participant refers to newspaper content on Johnson's personal life:

I know that the papers bring up stuff about his kids and relationships and stuff, but at the end of the day he's just a human being. We all make mistakes, he's not killed anyone, he's just sh*gged someone (Mick, retired electrician 2020, personal communication, $8^{\text {th }}$ February).

While a positive perception of Boris Johnson was most common across the participants, there were a significant minority of interviewees that held Johnson in low regard but still saw his leadership as preferable to that of Corbyn. The following quotation highlights this strand of opinion that was expressed by a selection of participants:

I don't particularly like Boris. I would say he was completely detached from the working-class. He's a bumbling idiot and super rich so there are things that he can't see, that he's never lived through. Having said that, I still think he's a safer bet than Corbyn. It's a poor do when the country has to pick between these two. (James, delivery driver 2019, personal communication, 21 st December)

Interestingly, when discussing party leaders, Tony Blair was often invoked as the type of Labour leader that these participants could support. One such example is found below, in which an interviewee brought up a discussion of Blair as a leader that captured his imagination:

I did like Tony Blair, and I know that's not popular anymore. I remember that the New Labour stuff was quite exciting. It seemed fresh, energetic, you know? When he was playing guitar with Noel Gallagher and that, doing headers with Kevin Keegan. (Adam, utilities operative 2020, personal communication, 7th March)

This comparison was brought up by a number of participants when issues of Leadership were discussed in these interviews. Here we see another example of Blair being used to characterise a vision of the Labour Party that these voters could support. 
At one time I did vote for Labour. If you think back to the Tony Blair days of Labour, Blair was more centre-ground. He could pull people like me who were on the edge to the Labour side if you know what I mean? (Kevin, window cleaner 2020, personal communication, 25th January)

The data covered in this section seem to provide a strong indication that the participants saw leadership as the key factor in their decision-making process. Damning indictments of Corbyn contrasted with positive assessments of Boris Johnson were the most common factors raised by interview respondents when asked what had guided their electoral choice. Many simply did not find Corbyn relatable, but held an opinion of Johnson whereby he was simultaneously seen as an elite operator worthy of deference, and a 'regular guy' that they could understand. Even those respondents that spoke negatively of Johnson still saw him as the lesser of two evils when compared with Corbyn. Furthermore, we see Tony Blair raised as an example of a Labour leader that the interviewees associated with an electable Labour Party. Key to many of these contributions is the presidential focus upon leaders as the personification of their party. This presidential focal point spilled through into other areas of the interviews. When respondents spoke of Brexit or matters of economic competence, it was clear that their assessments of the leaders had permeated all aspects of their wider decision-making. Let us explore this further as we turn to consider the manner in which Brexit featured in the narratives of the participants.

\section{Results 2: Brexit}

The majority of interviewees that participated in this research discussed Brexit as influential in their decision-making process. Most commonly, the participants spoke of a kind of Brexit fatigue that they felt that Boris Johnson would help to alleviate. This was frequently contrasted with a perception of Jeremy Corbyn as failing to offer leadership that could break the deadlock on this issue. We can see these ideas begin to take shape in the quotation below in which a participant discusses his desire to see an end to the Brexit debates, and the suggestion that Johnson would play a central role in achieving this outcome:

Look, I'm not exactly Mr Brexit. I didn't vote in the referendum, but they asked us and the people said they wanted to leave. So now it's been going on for years, literally about three years, I wanted to see the end of it. I'm bored of hearing about it. I want it gone. I think that Boris wants it done and he will get it done (Lee, roofer 2020, personal communication, 22nd February).

Similar views are expressed in the following interview fragment in which a participant outlines a sense of Brexit weariness, and a desire to see the issue moved from its dominant position in public debate. This interviewee couples up this argument with their perception that Johnson was seen as more likely to bring about an end to Brexit debates:

I was getting sick of Brexit. I was sick of the fallouts and the arguments and it seemed that Boris was more likely to get it sorted. I was just sick of it. I don't 
think that much is even going to change once it's all done though (Mark, textiles operative 2020, personal communication, 7th March).

This sense that the Conservatives were most likely to end the Brexit deadlock was generally contrasted with assessments of Labour, and particularly Jeremy Corbyn as being weak or duplicitous on Brexit. In this sense, the participants drew together their assessment of Corbyn's lack of leadership qualities and their desire to see Brexit over and done with. The quotation below highlights this trend through an explicit comparison of the party leaders and their positioning on Brexit:

Corbyn's stance on Brexit was a right mess. Just come out and say you want to leave or to stay. That's important. Even though Boris is a bumbling idiot, I could tell what he wanted to do with Brexit (Paul, butcher 2020, personal communication, 8th February).

In addition to those participants that perceived Corbyn as unclear on Brexit, a number of interviewees spoke of their sense that he was being deliberately evasive about his true views on Brexit. This is captured in the forthright appraisal of Corbyn's Brexit strategy expressed in the quotation below:

Corbyn has just been taking the $\mathrm{p}^{*}$ ss really, he wants to leave the EU, but he won't come out and say it because his supporters are a bunch of students who want to stay in. He's trying to have it both ways but people can see that its bullsh*t. I think that's why they lost (Gary, plumber 2020, personal communication, 18th January).

It may not come as much of a surprise that these participants held these views. The Conservative Party's pro-Brexit platform was hammered home with the 'Get Brexit Done' mantra that was central to their campaign (Usherwood 2019). That the Labour Party was deeply internally divided over Brexit was a matter of public record (Walker and Stewart 2019). However, it is important to note the manner in which these quotations seamlessly meld narratives on party leaders with discussions of Brexit fatigue. These voters wanted to see Brexit gone from the day-to-day mainstream of political debate, and they saw Johnson's leadership as central to achieving this aim. The issue was deeply intertwined with their assessments of the party leaders that were discussed in the previous section. This blending process between leadership and other issues will be explored further in the next section where we will shift our focus to the discussions of economic management explored during this research process.

\section{Results 3: economic management}

In addition to considerations about leadership and concerns about bringing Brexit to a conclusion, another common factor raised by participants was their perception of the economic competence of the two parties and their respective leaders. This has long been a problem for the Labour Party who have always struggled to maintain a reputation for economic competence (Hay and Watson 1999). This group of participants were particularly scathing about what they saw as a range of irresponsible and 
undeliverable promises made by the Labour Party, and principally Jeremy Corbyn. This contrasted with a broadly positive assessment of economic prospects under a Conservative government led by Johnson. We can see this argument in the quotation below in which the interviewee discusses his perception that Johnson would bring stability in the field of economic management:

I don't mind Boris. While he's in power I think the economy will keep moving. If the economy keeps moving and I can keep working, I can look after my kids and fix the roof if it needs fixing. If it doesn't, I can't. (Richard, plasterer 2019, personal communication, 22nd December)

This perception of the Conservatives and particularly Johnson as trustworthy guardians of the economy was a common theme across the interviews. We see a similar focus in the quotation below in which a positive assessment is made of the business credentials of the Conservative Party. Again, we see a specific focus on Johnson, marking his central position in these deliberations:

The Tories want to run the country like a business, or it crashes. I don't see how you can run it any other way. Boris Johnson gets that. The Conservatives just have a tight grip on the economy. They're all about business, aren't they? They know how to make money. They know how things work (Jason, groundworker 2020, personal communication, 21st March).

These positive predictions about how a Conservative government led by Johnson would run the economy were contrasted starkly with judgements on the fiscal credentials of the Labour Party. Labour was seen as likely to have a negative effect on the economy. Corbyn's leadership came up frequently as a central factor in these concerns. This is evident in the quotation below, where it is argued that Labour were making too many spending commitments that they were unlikely to deliver:

I mean when Corbyn is promising 'everything is free' kind of thing. I'm going to myself 'okay sounds nice', but you can't take that seriously though, can you? I might not be the brightest but I know that's not going to work. I did used to vote for Labour back in the New Labour days, but you can't take them seriously anymore (Andrew, gas-fitter 2020, personal communication, 8th March)

In some interviews, connections were drawn between perceptions of previous Labour governments having a negative effect on the economy and the present leadership. Here we see reference made to Gordon Brown's handling of the 2008 financial crisis. While Brown is not looked upon favourably in this assessment, his record of fiscal management is still seen as preferable to that of a hypothetical Corbyn administration:

I just don't have much belief in Labour anymore. I just don't believe that they can do what they say they are going to do without running the country into the ground and wrecking the economy again. If Gordon Brown managed to f*ck the economy then I'm sure Corbyn could make an even bigger c*ck-up. You can't risk it can you? (Daniel, painter and decorator 2020, personal communication, 11th January) 
While of course the headline here is that Labour were not trusted to run the economy and the Conservatives were, there is a distinct focus on leaders that underpin these narratives. Corbyn is at the centre of these assessments of Labour's economic policy. In discussions of Conservative economic management, Johnson is again the primary focus of the participant's deliberations. Even Sajid Javid and John McDonnell the respective chancellor, and shadow chancellor during this election did not feature at all in these appraisals of each party's hypothetical handling of the economy. Yet despite these strong views on Labour's economic competence, the majority of participants stated that they had a limited sense of attachment to the Conservatives, and would consider switching their vote to Labour if the party modified its approach in future. This will be explored during the final substantive section of empirical findings.

\section{Results 4: future voting}

When interviewees were asked about their future voting intentions, they would commonly discuss this in terms of a weak sense of attachment to the Conservative Party, and in some cases; a qualified preference to vote for the Labour Party, if it were to change leadership and policy direction. Additionally, many spoke of a debt that they perceived was owed to those who had voted Conservative, and a desire to see the government deliver changes that would affect themselves and their community. First let us outline the factors that would be likely to inculcate a more positive appraisal of the Labour Party among the participants. The quotation below exemplifies this approach, in which senior Labour figures were singled out as a blockage that had prevented this interviewee from voting for Labour in 2019:

Let me put it this way, I am no way a Tory. After this shower, Corbyn, Abbot and that lot have gone I will probably vote Labour again. I know that I didn't have to vote Tory, I could have not bothered, but I think we needed a government to actually make decisions or it would have been Brexit forever (Sam, machine driver 2019, personal communication, 15th December)

Once again, we see a keen focus on leadership as central to this participant's sense of what has shaped their vote and what might alter their choices in the future. Similar to our earlier discussion of Brexit, we see that this voter perceived the Conservatives as a party who would take decisive action, whereas Labour would not. In the quotation below, we see the participant explicitly state that Labour would need to move to a more moderate position on fiscal matters in order to secure their support in future elections. Additionally, in this fragment we see the focus shift to their sense that the government-and Johnson in particular-owe their electorate. Brexit is singled out as the key policy issue that this voter will be watching for signs of a satisfactory delivery during the current parliament:

If Labour were more centre-ground, if they had a more sensible approach to spending for instance, I would vote for them again. I think the Conservatives owe something to the people who voted for them though. Boris Johnson has borrowed these votes. I think if they get us out of the EU and people think he's 
done a good job. He might be borrowing those votes for a long time though

(Kevin, window cleaner 2020, personal communication, 19th January)

The suggestion that the government had a debt to repay to those who had given them office was reiterated in a number of the interviews. The fragment below offers a similar analysis, though in this discussion came a sense that northern England needed to be paid specific attention by the government. The high-speed rail network (HS2) is invoked as a symbol of what is needed to unite the country and deliver prosperity to the north. This participant also speaks of a fairly weak sense of attachment to the Conservative Party that may be subject to change in future, if their expectations of the government are not delivered:

I don't think I would always vote Tory from now on. I think I will probably change again in the future. I will be watching what happens in the north. I think that Boris owes the north after we've voted for him. If he can pull the country together it would be a legacy for Boris. If he got HS2 done, it would be like saying, 'it's not just about London, it's about everyone'. Now that might mean he would keep my vote (Marcus, barman 2020, personal communication, 29th February).

These pieces of evidence fit with the broader themes discussed in this paper. There is a keen focus on perceptions of the party leaders that comes to the fore when considering what may shape the future voting choices of the participants. The desire to see Brexit concluded, and doubts about Corbyn's spending policies surfaced again in these quotations. However, the overriding theme was a sense of relatively limited connection to the Conservative Party. If this is a period of class realignment, it is a fairly unsteady one. These voters are keen to see policies that deliver for them before they make up their mind whether to vote for the Conservatives in future elections. They are also interested to see a change of leadership and a shift in policy direction before they would consider voting for Labour in future. Let us now move to consider these findings in their totality, and to consider what they might mean for the two largest parties as they look towards future electoral contests.

\section{Discussion and conclusion}

This paper has put some qualitative flesh on the bones of survey research into how and why working-class voters in Northern England came to the decision to vote for the Conservative Party in 2019. We knew that Brexit and Corbyn were significant problems for the Labour Party in terms of their ability to attract the support of certain sections of the electorate. The data captured here give a sense of the specific thought processes that were used by these voters when casting their vote across a selection of interrelated factors. Furthermore, the evidence seems to suggest that if 2019 is a moment of class realignment in British politics, it is built on shaky ground, with a fairly limited attachment between working-class voters and the Conservative Party beyond Johnson's personal appeal and the predominance of the Brexit issue. 
Perceptions of leadership and personality sit at the heart of these accounts of contemporary political issues. This sample of working-class Conservative voters from a marginal constituency in northern England tells us that leadership permeated wider areas of the debate for this group of voters. In the first instance, the participants simply did not respond to Corbyn. To them he seemed to represent the epitome of duplicity and indecision, they perceived that he lacked the qualities of charisma and relatability. Johnson on the other hand was seen to simultaneously offer elite standards of leadership whilst retaining a likeability, and the sense of being a 'regular guy'. This focus on leaders was clearly central to the decision-making processes of these voters. Whereas survey-based studies asked respondents to rate the issues that were most important in shaping their vote, this research-through examining these narratives-has made it possible to offer a deeper insight into the interconnected nature of these factors for this cohort of participants.

Leadership spilled over into questions about Brexit and the economy. These voters used the party leaders as gravitational centre-points: their wider policy stances orbited around the central body of leadership. When discussing Brexit, we saw that Corbyn was seen as indecisive or deceitful on this issue, whereas Johnson was thought of as robust and clear. On the economy, we saw the perception of Johnson as a safe pair of hands contrasted with Corbyn as the author of financial fairy tales. When we discussed future voting strategies, we saw that perceptions of whether Johnson delivered, or Labour changed its leadership were central. Throughout all of these discussions there was a pervading presidential focus upon the party leaders that will have implications for future elections.

Things look bleak for Labour, given their current electoral position and the wider structural issues that the party faces. That said, the party should not underestimate the importance of adopting a leader that can project a more centrist image. The data showed on multiple occasions that these respondents had particular problems with the Labour Party that they felt could be overcome by a change of leadership and a shift in policy direction. Keir Starmer has begun to make a break with the Corbynite left following his shadow cabinet reshuffle, though it remains to be seen what wider policy platform will emerge under his leadership. The party has the difficult task of offering something that retains the support of their young, urban electorate, yet also reaches out to the northern constituencies that have been ceded in 2019. This research suggests that if Labour are to take back some of the party's seats in the predominantly working-class areas of northern England, they will need to project a more moderate image-particularly in economic matters-yet this does not resolve the party's challenge of holding together its various factions.

Fortunately for the Labour Party, the question of whether, and how, the UK should leave the EU will not dominate this parliament as it did the last one. Johnson's clear parliamentary majority means that one way or another this matter will be settled in the fashion that the government sees fit. This offers a possibility for the opposition to lead on the effects of government Brexit policy rather than the direction. In short, if Brexit delivers a tumultuous time for the economy, Labour can potentially benefit, and the government will have to account for their choices. This has the potential to shift the manner in which swing voters perceive the government's economic management and their general policy direction on Brexit. 
For the Conservatives, it seems that in Johnson they have a leader that can inspire certain sections of the electorate through personal charisma and by striking the correct balance between elite and relatable qualities. Many of the respondents in this research seemed to have a real sense of personal loyalty towards Johnson, though his credibility has taken a hit due to perceptions of his handling of the COVID-19 pandemic. Furthermore, we have seen that these participants have a weak attachment to the Conservative Party more generally. They will be watching closely to see whether this government delivers what it has promised or can at least appear to have done so. This raises two issues for the Conservative Party: firstly, they need to be seen to deliver something tangible that impacts positively upon the Northern constituencies they took in the 2019 election: this may be easier said than done. Secondly, this stream of support is heavily dependent on Johnson personally. If his stock goes down with the electorate, we might expect the Conservative Party to feel some negative effects. Furthermore, it would be difficult to replace Johnson with someone who has the same selection of characteristics that appealed to certain sections of the electorate during the 2019 election. For both parties, it seems that perceptions of leadership are likely to determine whether they can retain or regain the loyalties of these voters in coming elections.

\section{References}

Carreras, M., Y. Irepoglu Carreras, and S. Bowler. 2019. Long-term economic distress, cultural backlash, and support for Brexit. Comparative Political Studies 52 (9): 1396-1424.

Clark, T.N., and S.M. Lipset. 1991. Are social classes dying? International Sociology 6 (4): 397-410.

Crewe, I. 1986. On the death and resurrection of class voting: Some comments on How Britain Votes. Political Studies 34 (4): 620-638.

Curtice, J. 2020. Brave new world: Understanding the 2019 general election. Political Insight 11 (1): $8-12$.

Cutts, D., M. Goodwin, O. Heath, and P. Surridge. 2020. Brexit, the 2019 General Election and the realignment of British politics. The Political Quarterly. https://doi.org/10.1111/1467-923X.12815.

Dunleavy, P. 1987. Class dealignment in Britain revisited. West European Politics 10 (3): 400-419.

Dworkin, S.L. 2012. Sample size policy for qualitative studies using in-depth interviews. Archives of Sexual Behavior 6 (41): 1319-1320.

Elliot, L., K. Proctor, and R. Partington. 2020. McDonnell and Starmer show split on Labour's Brexit stance. https://www.theguardian.com/politics/2020/feb/16/mcdonnell-and-starmer-show-split-onlabours-brexit-stance. Accessed 28 Mar 2020.

Evans, G., and J. Mellon. 2020. The Re-shaping Of Class Voting. https://www.britishelectionstudy.com/ bes-findings/the-re-shaping-of-class-voting-in-the-2019-election-by-geoffrey-evans-and-jonathanmellon/\#.YAgNJ-j7RPY. Accessed 20 Jan 2020.

Evans, G., and J. Tilley. 2012. How parties shape class politics: Explaining the decline of the class basis of party support. British Journal of Political Science 42 (1): 137-161.

Ford, R., and M.J. Goodwin. 2010. Angry white men: Individual and contextual predictors of support for the British National Party. Political Studies 58 (1): 1-25.

General Elections Online. 2020. Colne Valley - 2017 Election Results. https://electionresults.parliament. uk/election/2017-06-08/results/Location/Constituency/Colne\%20Valley. Accessed 07 April 2020.

Hall, S., and M. Jacques. 1989. New times: The Changing face of politics in the 1990s, 1-23. London: Lawrence \& Wishart.

Halliday, J. 2019. Labour's 'red wall' demolished by Tory onslaught. https://www.theguardian.com/polit ics/2019/dec/13/labours-red-wall-demolished-by-tory-onslaught . Accessed 02 April 2020. 
Hay, C., and M. Watson. 1999. Labour's economic policy: Studiously courting competence. In The impact of new labour, ed. G.R. Taylor, 149-161. London: Palgrave Macmillan.

Heath, A., R. Jowell, and J. Curtice. 1987. Trendless fluctuation: A reply to Crewe. Political Studies 35 (2): $256-277$.

Heppell, T. 2008. The degenerative tendencies of long-serving governments... 1963... 1996... 2008? Parliamentary Affairs 61 (4): 578-596.

Hollway, W., and T. Jefferson. 1997. Eliciting narrative through the in-depth interview. Qualitative Inquiry 3 (1): 53-70.

Hughes, L. 2019. Defeated Labour MPs hit out at 'cronyism' in party's leadership. https://www.ft.com/ content/c4043f2a-2a2b-11ea-bc77-65e4aa615551. Accessed 11 April 2020.

Inglehart, R. 1977. Values, objective needs, and subjective satisfaction among western publics. Comparative Political Studies 9 (4): 429-458.

King, A. 2002. Do leaders' personalities really matter. In Leaders' personalities and the outcomes of democratic elections, ed. A. King, 1-43. Oxford: Oxford University Press.

Labour for the North. 2020. Labour's northern soul: how Labour rebuild the red wall across the north. https://labourlist.org/wp-content/uploads/2020/12/Labours-Northern-Soul-\%E2\%80\%94-HowLabour-Can-Rebuild-the-Red-Wall-Across-the-North.pdf. Accessed 19 Jan 2021.

Lavigueur, N. 2017. Which Kirklees constituency voted against Brexit? https://www.examinerlive.co.uk/ news/west-yorkshire-news/kirklees-constituency-voted-against-brexit-12593757. Accessed 29 Mar 2020.

Lavigueur, N. 2019. Jason McCartney takes back Colne Valley from Thelma Walker. https://www.exami nerlive.co.uk/news/west-yorkshire-news/jason-mccartney-takes-back-colne-17407671. Accessed 08 April 2020.

Lilleker, D.G. 2002. Whose left? Working-class political allegiances in post-industrial Britain. International Review of Social History 47 (S10): 65-85.

Morris, S. 2019. Ex-Labour MPs blame Jeremy Corbyn for party's crushing defeat. https://www.belfa sttelegraph.co.uk/news/uk/ex-labour-mps-blame-jeremy-corbyn-for-partys-crushing-defeat-38784 780.html. Accessed 28 Mar 2020.

Mughan, A. 2009. Partisan dealignment, party attachments and leader effects. Journal of Elections, Public Opinion and Parties 19 (4): 413-431.

Mughan, A. 2015. Parties, conditionality and leader effects in parliamentary elections. Party Politics 21 (1): 28-39.

Parliament Online. 2020. General elections and by-elections. http://www.data.parliament.uk/dataset/elect ions. Accessed 28 Mar 2020.

Pulzer, P. 1967. Political representation and elections: Parties and voting in Great Britain, 98. New York: Praeger.

Savage, M., F. Devine, N. Cunningham, M. Taylor, Y. Li, J. Hjellbrekke, B. Le Roux, S. Friedman, and A. Miles. 2013. A new model of social class? Findings from the BBC's Great British Class Survey experiment. Sociology 47 (2): 219-250.

Usherwood, S. 2019. Getting Brexit done, or getting Brexit done right? Political Insight 10 (4): 32-34.

Walker, P., and S. Stewart. 2019. Competing divisions of Labour's Brexit debate. https://www.theguardian.com/politics/2019/feb/26/a-guide-to-labours-brexit-tribes. Accessed 11 April 2020.

Webb, P., and T. Poguntke. 2013. The presidentialisation of politics thesis defended. Parliamentary Affairs 66 (3): 646-654.

YouGov. 2019a. In their own words: Why voters abandoned Labour. https://yougov.co.uk/topics/politics/ articles-reports/2019/12/23/their-own-words-why-voters-abandoned-labour. Accessed 1 April 2020.

YouGov. 2019b. How Britain voted in the 2019 general election. https://yougov.co.uk/topics/politics/artic les-reports/2019/12/17/how-britain-voted-2019-general-election Accessed 02 April 2020.

Publisher's Note Springer Nature remains neutral with regard to jurisdictional claims in published maps and institutional affiliations. 